\title{
A EXTERIORIDADE NA PRODUÇÃO DO CONHECIMENTO E DO SENTIDO
}

\author{
Exteriority in the Production Exterioridad en la producción \\ of Knowledge and Meaning de conocimiento y sentido
}

\author{
Juliana de Castro Santana* \\ Faculdade de Tecnologia Professor Francisco de Moura - FATEC, Jacareí, SP, Brasil
}

\begin{abstract}
Resumo: Este estudo teórico-analítico, ancorado na Análise de Discurso, reflete sobre o funcionamento da linguagem no que se refere à produção do conhecimento e de sentido(s) sócio-historicamente compartilhados, considerando que não é possível significar o mundo fora da linguagem. Percorre a hipótese de que o funcionamento do corpo, a produção de sentidos e o processo de produção do conhecimento científico se assemelham ao funcionamento da linguagem, porque, de fato, tudo é linguagem. Para tanto, explora a relação entre língua, vazio, silêncio e sentido(s), partindo de um conto de Kafka e da metáfora do vaso e do oleiro, de Heidegger, sem perder de vista o processo de produção do conhecimento e sua relação com a linguagem e os gestos de interpretação. A análise sugere que no cerne da produção do conhecimento não está a essência, o objeto real ou a substância, mas sim o silêncio, o vazio, a barreira e a contradição.
\end{abstract}

Palavras-chave: Conhecimento Científico. Exterioridade. Linguagem. Análise de Discurso.

\begin{abstract}
In this theoretical and analytical study, supported by the Discourse Analysis, we reflect upon the functioning of language in relation to the knowledge production and sociohistorically shared meanings, considering that it is not possible to constitute the world without language. The hypothesis is that the functioning of the body, the production of meanings and the process of scientific knowledge production are similar to the functioning of language, because everything is language. In order to investigate that, we explore the relation between language, emptiness, silence and meaning(s), starting from a tale by Kafka and the Heidegger's metaphor the pot and the potter, without losing sight of the knowledge production process and its relation with language and interpretation. Our analysis suggests that the essence, real object, or the substance is not in the core of the knowledge production, but rather the silence, emptiness, barrier and contradiction.
\end{abstract}

Keywords: Scientific Knowledge. Exteriority. Language. Discourse Analysis.

Resumen: Este estudio teórico-analítico, anclado en el Análisis del Discurso, reflexiona sobre el funcionamiento del lenguaje en cuanto a la producción de conocimiento y significados sociohistóricos compartidos, considerando que no es posible significar el mundo fuera del lenguaje. Pasa por la hipótesis de que el funcionamiento del cuerpo, la producción de significados y el proceso de producción del conocimiento científico son similares al funcionamiento del lenguaje, porque, en realidad, todo es lenguaje. Para ello, explora la relación entre lenguaje, vacío, silencio y significado (s), a partir de un cuento de Kafka y la metáfora del jarrón y el alfarero, de Heidegger, sin perder de vista el proceso de producción del conocimiento y su relación con el lenguaje y los gestos de interpretación. El análisis sugiere que en el corazón de la producción de conocimiento no está la esencia, el objeto real o la sustancia, sino el silencio, el vacío, la barrera y la contradicción.

Palabras Clave: Conocimiento científico. Exterioridad. Lenguaje. Análisis del Discurso.

* Doutora em Linguística Aplicada pela Unicamp. Professora associada III na Faculdade de Tecnologia. ORCID: https://orcid.org/0000-0002-8245-7922. E-mail: julianacastrosantana@hotmail.com. 
" $[\ldots]$ a inteligência humana $[\ldots]$ se origina na

incontornável ambiguidade das línguas naturais, nos limites da transparência de todo pensamento [...]"

(PÊCHEUX, 1966 [2016, p. 11])

\section{INTRODUÇÃO}

Considerando que não é possível estar no mundo e significa-lo fora da linguagem, pois esta é mediadora da relação estabelecida entre o homem e sua realidade material (ORLANDI, 1999), nos colocamos a refletir sobre o funcionamento da linguagem no que se refere, mais especificamente, à produção do conhecimento e de sentidos sóciohistoricamente compartilhados. Com base nos pressupostos da Análise de Discurso (AD), pareceu-nos, a princípio, que toda produção do conhecimento, em especial o conhecimento sustentado e legitimado pelo discurso da ciência, se assemelhava ao funcionamento da linguagem, tal como a concebemos na perspectiva da $\mathrm{AD}$, segundo a qual o(s) sentido(s), por não ter(em) uma relação direta e biunívoca com a palavra e com a realidade material, se produz $(\mathrm{em})$ sempre em relação à exterioridade, isto é: segundo as condições materiais de existência, as formações imaginárias, a historicidade e o trabalho da ideologia.

Posteriormente, pareceu-nos mais acertado levantar a hipótese de que tudo parece ser semelhante ao funcionamento da linguagem porque, de fato, tudo é linguagem. Ao dizermos tudo, estamos nos referindo, mais especificamente, ao funcionamento do corpo, que não é só biológico, à produção de sentidos e ao processo de produção do conhecimento científico, de modo a compreendermos suas práticas e efeitos. É esta hipótese que buscamos contemplar, ilustrar e fundamentar ao longo deste ensaio teóricoanalítico. Vale destacar que a ideia inicial para desenvolver este estudo ocorreu durante uma consulta médica, na qual uma endocrinologista explicava o funcionamento das células. Antes que ela terminasse sua explicação, eu a interrompi e finalizei a explicação, como se soubesse do que estava falando. Naquele momento, a médica se surpreendeu e perguntou se eu havia cursado medicina ou biologia. Eu respondi que não, mas que, de algum, modo intuía como era o funcionamento celular, pois ele se aproximava do funcionamento da linguagem e da produção de sentidos.

Segundo a perspectiva discursiva, não devemos perder de vista a relação entre o linguístico e o extralinguístico, a espessura histórica da língua, a relação entre a estrutura e o acontecimento na produção de sentidos que resultam de gestos de interpretação singulares. Essas relações, que estão na base da constituição dos sujeitos e dos sentidos, são exploradas ao longo deste estudo. Para tanto, buscamos ancorar nossas discussões em postulados de relevantes estudiosos da linguagem, bem como em exemplos e/ou metáforas que ilustrem nossos apontamentos.

\section{PROCESSO DE PRODUÇÃO DO CONHECIMENTO CIENTÍFICO}

Fazendo um paralelo entre a linguagem, a produção de sentido(s) e o corpo biológico, podemos afirmar que assim como a estrutura sintática (a base linguística) não é, por si só, determinante para a produção de certos sentidos que podem sempre tornar-se 
outro (PÊCHEUX, 1997, p. 53), dependendo das condições de sua enunciação e de fatores extralinguísticos; o corpo biológico, a célula e mesmo o DNA, cujas moléculas carregariam as instruções genéticas que coordenam o desenvolvimento dos seres vivos, podem não ser determinantes, no que tange às possibilidades de enfermidades e até de óbito, por exemplo. Chiaretti (2017, p. 160) propõe uma relação sinonímica entre DNA e texto, já que ambos se mostram passíveis de edição na atualidade. O genoma humano, salienta a referida autora, seria significado como uma espécie de matriz simbólica ou de texto fundamental do sujeito, no qual tudo se apresenta de forma unívoca e transparente.

No entanto, se pensarmos que a linguagem é metafórica por excelência e está sempre afetada pela possibilidade do equívoco e da contradição, não há texto que produza um sentido único e imutável. O discurso médico, por exemplo, prega que os fatores externos como alimentação, estilo de vida, a prática de exercício físico, acesso à saúde, boas condições socioeconômicas podem alterar e até modificar certas condições biológicas do organismo, produzindo, em alguns casos, um "destino" diferente daquele indicado num mapeamento genético, que, apesar de estar amparado por critérios científicos, pode sempre falhar, por se tratar de um saber que não pode ser produzido fora da linguagem e dos gestos de interpretação.

Podemos pensar na descrição do DNA como lugar de textualização do discurso científico, que se pretende neutro, mas é posto em circulação por sujeitos que assumem diferentes posições e lugares sociais, nos processos de produção do conhecimento, através das diferentes práticas e processos discursivos atravessados pelo ideológico e pelo político, entendido, aqui, como divisão do sujeito e dos sentidos. O discurso científico se faz ideológico e marcadamente político quando "elege" um objeto de conhecimento (o DNA enquanto composto químico/orgânico que é objeto apreensível e passível de descrição) e produz um gesto de interpretação sobre o que supõe ser o objeto real (o DNA como algo que "determina" aptidões naturais e potenciais de desenvolvimento do indivíduo não só bio-psico, mas também do indivíduo histórico-social, uma vez que essas determinações de cunho científico incidem diretamente em sua constituição). Retomando uma das máximas saussurianas, "Longe de dizer que o objeto precede o ponto de vista, diríamos que é o ponto de vista que cria o objeto." (SAUSSURE, [1916] 1994, p. 15).

Sobre a prática teórica que, segundo Pêcheux ${ }^{1}$ ([1966] 2016, p. 25), está no cerne da produção dos conhecimentos científicos há, por meio desta prática, "a transformação de um produto ideológico em conhecimento teórico, por meio de um trabalho conceitual determinado. O desligamento da teoria em relação à ideologia constitui o 'corte epistemológico"'. Assim sendo, para que o conhecimento teórico seja produzido é preciso haver o apagamento do ideológico, produzindo o efeito de que é o objeto que cria o ponto de vista, como se o exterior ou a exterioridade não fossem determinantes para o funcionamento interno de uma prática. Ao refletir sobre a Alquimia, a Ciência e as práticas que derivam dela, Pêcheux postula que é o "ponto de vista interpretativo que 'dita o real', o ponto que 'sempre-já' fala para dizer aquilo que é, como se o próprio real [leia-se objeto da ciência] falasse" e, diríamos ainda, como se toda e qualquer prática não estivesse inserida no universo simbólico; como se não houvesse língua...

\footnotetext{
1 Trata-se de um capítulo que Michel Pêcheux assina como Thomas Herbert, em 1966, e que foi recentemente publicado em um livro organizado por Orlandi (2016).
} 
Podemos afirmar, portanto, que assim como a língua não nos dá acesso direto ao referente, o discurso da ciência, enquanto resultante de uma prática social em estreita relação com uma prática técnica que produz efeitos e saberes no mundo, é uma discursividade que gira em falso, sem atingir o real que é impossível de simbolizar ou alcançar. Assim como a língua é uma forma e não uma substância (SAUSSURE, 1994 [1916], p. 131), o discurso da ciência parece ser uma forma de fazer coincidir o objeto real com o objeto do conhecimento, produzindo um efeito de verdade e de unidade que, vez por outra, vacila graças à ordem própria da língua. Ao abordar a representação escolar da ciência, em especial da Física, Pêcheux ([1966] 2016, p. 32) salienta que esta é "uma hipótese que deu certo, uma resposta simulada que mostrou ser de conformidade com o real, quer dizer, entendida a partir daí como uma prática técnica". Trata-se, portanto, de uma combinação de saberes, a princípio aleatória e contingencial, que, por meio de práticas técnicas, passa a produzir um efeito de objetividade, realidade e de verdade. Nas palavras de Pêcheux ([1966] 2016, p. 31), "toda técnica é realista, na medida em que ela provoca uma resposta do 'real' a suas questões". Diríamos, portanto, que a prática técnica busca fazer coincidir as leis do acaso. "A técnica se declara adequada ao real: dito de outra forma, ela o realiza sob uma forma manipulável” (PÊCHEUX, [1966] 2016, p. 31) em que os gestos de interpretação e o ideológico são apagados.

Paul Henry (2013), retomando Althusser ${ }^{2}$ sobre a distinção objeto real / objeto do conhecimento, ressalta a relação contraditória que se inscreve na produção do conhecimento. A contradição, portanto, é constitutiva do objeto próprio de uma ciência. "O que deve ser levado em conta, segundo o referido autor (2013, p. 27), é o par ciênciasideologias no processo de produção de conhecimento, e não apenas um dos dois termos; a divisão, o par, realizando-se concretamente de maneiras diferentes, de acordo com o modo de produção [...]". Lembrando que não há produção de conhecimento fora da linguagem, podemos dizer que o objeto da ciência é tão contraditório e opaco como a própria língua posta em funcionamento. Ao retomar Frege sobre as questões do léxico e de referência, Henry $(2013$, p, 13) postula que "a língua permite criar um mundo de ficções, dar aparência de que os objetos existem, quando eles não existem”. A língua produz um efeito de presença do objeto ou do referente que, na verdade, está ausente da cena enunciativa.

Sobre a materialidade do objeto do conhecimento que possui uma espessura histórica, produzindo-se sob determinadas condições, Henry (2013, p. 16-17) destaca que

O objeto de conhecimento é tão material quanto o objeto real, mas ele é materialmente distinto. Reconhecê-lo permite precisar em que consiste a materialidade do objeto de conhecimento sem reduzi-lo a um reflexo pensado do objeto real. O objeto de conhecimento é objeto que muda, que tem uma história inscrita na história da ciência da qual é objeto, na confrontação de suas teorias, nas práticas específicas que o caracterizam, assim como nas condições históricas que produziram essa história, essas confrontações, essa prática. [...] A contradição não é, portanto, essencial; ela não faz parte da 'ordem das coisas', mas se inscreve no processo de produção dos conhecimentos enquanto processo histórico em que as ciências não estão sozinhas. [...] não se trata de eliminar essa contradição, mas apenas de reconhecer que praticar uma ciência é sempre, em última instância, trabalhar sua contradição específica de modo que o exame das diversas formas concretas dessa contradição permita a depreensão de seus elementos.

${ }^{2}$ Ler O Capital vol. 1, p. 46-50. 
Pêcheux ([1966] 2016, p. 21) também se aprofunda na discussão sobre os diferentes modos de apropriação do real pelo conhecimento, sobretudo ao abordar a relação entre práticas técnicas, políticas, ideológicas e teóricas, no âmbito mais geral das práticas sociais, destacando a relação conflituosa e contraditória entre as "ciências exatas" e as "ciências sociais", cujos objetos mantêm relações distintas com o real. A perspectiva discursiva nos lança à contradição que, embora apagada ou silenciada, está na base da produção do conhecimento e das práticas sociais, uma vez que não há um fora da língua e de seu funcionamento. Na sequência, buscamos explorar a relação entre vazio, silêncio e produção de sentido(s).

\title{
3 A LEI, O VAZIO E O SILÊNCIO NA PRODUÇÃO DOS SENTIDOS
}

Para ilustrar nossas proposições, reproduzimos, abaixo, um conto de Kafka, já discutido por Agamben (2010), sobre o soldado que guarda a Lei, para, em seguida, propormos algumas aproximações que irão endereçar a hipótese postulada neste ensaio teórico de que tudo parece ser semelhante ao funcionamento da linguagem porque, de fato, tudo é linguagem. Passemos ao conto:

\begin{abstract}
Diante da Lei está um guarda. Vem um homem do campo e pede para entrar na Lei. Mas o guarda diz-lhe que, por enquanto, não pode autorizar-lhe a entrada. O homem considera e pergunta depois se poderá entrar mais tarde. - "É possível" - diz o guarda. - "Mas não agora!". O guarda afasta-se então da porta da Lei, aberta como sempre, e o homem curva-se para olhar lá dentro. Ao ver tal, o guarda ri-se e diz. - "Se tanto te atrai, experimenta entrar, apesar da minha proibição. Contudo, repara, sou forte. E ainda assim sou o último dos guardas. De sala para sala estão guardas cada vez mais fortes, de tal modo que não posso sequer suportar o olhar do terceiro depois de mim”. O homem do campo não esperava tantas dificuldades. A Lei havia de ser acessível a toda a gente e sempre, pensa ele. Mas, ao olhar o guarda envolvido no seu casaco forrado de peles, o nariz agudo, a barba à tártaro, longa, delgada e negra, prefere esperar até que lhe seja concedida licença para entrar. O guarda dálhe uma banqueta e manda-o sentar ao pé da porta, um pouco desviado. Ali fica, dias e anos. Faz diversas diligências para entrar e com as suas súplicas acaba por cansar o guarda. Este faz-lhe, de vez em quando, pequenos interrogatórios, perguntando-lhe pela pátria e por muitas outras coisas, mas são perguntas lançadas com indiferença, à semelhança dos grandes senhores, no fim, acaba sempre por dizer que não pode ainda deixá-lo entrar. O homem, que se provera bem para a viagem, emprega todos os meios custosos para subornar o guarda. Esse aceita tudo, mas diz sempre: - "Aceito apenas para que te convenças que nada omitiste". Durante anos seguidos, quase ininterruptamente, o homem observa o guarda. Esquece os outros e aquele afigura ser-lhe o único obstáculo à entrada na Lei. Nos primeiros anos diz mal da sua sorte, em alto e bom som e depois, ao envelhecer, limita-se a resmungar entre dentes. Torna-se infantil e como, ao fim de tanto examinar o guarda durante anos lhe conhece até as pulgas das peles que ele veste, pede também às pulgas que o ajudem a demover o guarda. Por fim, enfraquece-lhe a vista e acaba por não saber se está escuro em seu redor ou se os olhos o enganam. Mas ainda apercebe, no meio da escuridão, um clarão que eternamente cintila por sobre a porta da Lei. Agora a morte está próxima. Antes de morrer, acumulam-se na sua cabeça as experiências de tantos anos, que vão todas culminar numa pergunta que ainda não fez ao guarda. Faz-lhe um pequeno sinal, pois não pode mover o seu corpo já arrefecido. O guarda da porta tem de se inclinar até muito baixo porque a diferença de alturas acentuou-se ainda mais em detrimento do homem do campo. - "Que queres tu saber ainda?", pergunta o guarda. - "És insaciável”. - "Se todos aspiram a Lei”, disse o homem. - "Como é que, durante todos esses anos, ninguém mais, senão eu, pediu para entrar? ". O guarda da porta, apercebendo-se de que o homem estava no fim, grita-lhe ao ouvido quase inerte: "Aqui ninguém mais, senão tu, podia entrar, porque só para ti era feita esta porta. Agora voume embora e fecho-a".
\end{abstract}


Com base no conto acima, Agamben (2010, p. 57) se interroga sobre a Lei que vigora, que exerce um poder soberano, mas que não significa. $O$ real da Lei, o que a sustenta, parece ser inatingível e guardado a sete chaves. A porta da Lei, neste prisma, guardaria o nada, o vazio e, ao contrário do que se costuma pensar, a Lei não é uma entidade absoluta e imutável, à espera de ser desvendada. Ninguém, além do homem simples do campo, pede para adentrar a porta da lei que, para a maioria das pessoas, se apresenta como algo evidente e já em vigência, por isso não precisaria ser vista ou explicada. Trazendo essa discussão para questões acerca da língua(gem), podemos afirmar que a estrutura da lei se aproxima à estrutura da língua que possui uma combinação sintática mais ou menos rígida, à qual o falante precisa se submeter, embora a relação entre significado e significante, entre palavra e coisa, entre estrutura e acontecimento discursivo se sustente sobre o nada ou, empregando termos oriundos da Linguística, se sustente na arbitrariedade do signo linguístico e na ambiguidade irredutível das línguas naturais. É o nada que tanto guardamos e que nos escapa e sempre nos escapará, pois não é passível de instrumentalização. O sentido não está colado à palavra, por isso se movimenta.

Em geral, sobretudo no discurso da ciência que se pretende neutro, imparcial, objetivo e legítimo, acredita-se ser possível ter acesso direto à substância, ao objeto real. A forma como o conhecimento que orienta as diversas práticas sociais (práticas médicas, escolares, jurídicas, etc.) é produzido parece ser apagada. Propondo um paralelo entre o conto acima e o funcionamento da linguagem, podemos afirmar que o soldado guarda $o$ conhecimento que não é dado a priori, que não tem uma essência ou uma verdade essencial a ser resgatada, já que o conhecimento é tão fluido e opaco quanto a linguagem empregada para produzir 'verdades' científicas. Em outras palavras, o discurso da ciência é (e)feito de linguagem, que é falha e faltosa por excelência, já que algo sempre escapa à simbolização.

A metáfora do vaso e do oleiro, proposta por Heidegger e revisitada nos postulados lacanianos, pode nos ajudar a compreender a função do vazio no processo de produção do conhecimento e dos sentidos. De acordo com Corrêa,

\footnotetext{
O vazio como tal é algo em torno de que eu também posso construir alguma coisa. A metáfora é de Heidegger (1956), com a questão do oleiro. Heidegger questiona qual é a matéria prima do oleiro. É o barro que ele vai utilizar ou é o vazio? O barro para o oleiro vai ser a borda, mas o que vai fazer com que o vaso, o pote, seja de determinada forma é o vazio que vai estar circundado por essa argila. [...] Esse vazio é exatamente aquilo que o oleiro vai utilizar para circundar com argila e fazer os vasos das formas mais diversas possíveis (CORRÊA, 2001, p. 57).
}

Valendo-nos da metáfora acima, podemos questionar qual seria a matéria prima que está na base da produção do sentido e do conhecimento. Seria a estrutura sistematizável e lógica da língua ou o exterior impalpável e não substancializável que a constitui? Poderíamos pensar que a estrutura da língua é o barro, que a torna palpável, ao passo que o sentido nos remete ao vazio, já que está em constante movimento? O sistema de leis (eixos da seleção e da combinação) que rege a língua é a borda do falante que não pode dizer qualquer coisa de qualquer maneira, sem levar em conta o eixo sintagmático e paradigmático (SAUSSURE, [1916] 1994) que estrutura a língua. No entanto, o signo 
linguístico é necessariamente arbitrário, segundo Saussure, pois não há uma relação predeterminada e natural entre significado e significante. Daí a importância, para a compreensão produzida pela $\mathrm{AD}$, desse vazio que é esquecido, impalpável, mas que significa, pois traz em seu bojo determinações sócio-históricas que estão em constante mutação. Em outras palavras, o que vai fazer com que o sentido e o conhecimento sejam produzidos de determinada forma é o modo como a linguagem e a exterioridade se relacionam. Assim como não há uma forma predefinida para a feitura do vaso, não há uma forma já determinada e imutável para o sentido. $\mathrm{O}$ vazio não está atrelado à falta de sentido, mas à indeterminação do sentido. Em outras palavras, o sentido é vazio, mas se apresenta como pleno para o sujeito de linguagem, graças ao trabalho da ideologia na produção de evidências discursivas. Retomando Orlandi (2007), podemos afirmar que o silêncio é um vazio fecundo, pois funda a possibilidade da linguagem.

Na mesma direção, Lacan ([1971-1972] 1997, p. 53) propõe a metáfora da linguagem como uma barreira resistente à significação e que barra a relação direta entre o ser falante e o mundo, como um muro que circunda um vazio do qual se obtém um além e aquém de sentido. Há sempre um resto que resiste à significação. Nas palavras de Rehem (2016, p. 334),

\footnotetext{
É "no pé do muro da linguagem" (Lacan apud Allouch 2010, p. 287) que o ser falante irá alinhavar os efeitos da articulação da cadeia significante advindos da sua relação com as coisas do mundo. Esta res, esta coisa, não se trata daquilo que compõe a realidade no âmbito da ciência, mas de um real que somente pode ressoar na lalangue.
}

Para adentrar a relação entre vazio, silêncio, língua(gem) e sentidos, é relevante retomarmos a noção de silêncio fundador como matéria significante por excelência e de linguagem enquanto prática de recortar esse silêncio em unidades discretas, tal como proposto por Orlandi (2007). Trata-se da ausência fundadora que clama por uma presença material e que está no cerne do funcionamento da linguagem e dos sentidos por ela produzidos. O silêncio, na relação com o dizível, é fundante e fundador. Não se trata do silêncio como ausência de palavras e de significação, mas como possibilidade do sentido outro, como espaço para o equívoco, lugar potencial de/para significação. Mais especificamente sobre a estreita relação entre linguagem, silêncio e significação, Orlandi (2007, p. 32) diz que

\footnotetext{
A linguagem é conjunção significante da existência e é produzida pelo homem, para domesticar a significação. [...] O silêncio não está disponível à visibilidade, não é diretamente observável. Ele passa pelas palavras. Não dura. Só é possível vislumbrá-lo de modo fugaz. Ele escorre por entre as tramas da fala.
}

Tendo em vista que o silêncio "não fala, ele significa" (ORLANDI, 2007, p. 42), passamos a compreender o silêncio não pela atribuição de um sentido metafórico em sua relação com o dizer, mas por meio dos processos de significação que ele põe em jogo. $\mathrm{O}$ silêncio fundador é definido como "aquele que existe nas palavras, que significa o nãodito e que dá espaço de recuo significante, produzindo as condições para significar" (ORLANDI, 2007, p. 24). Sobre a diferença entre a política do silêncio, que se impõe de fora para dentro, nas/pelas relações de poder e o silêncio fundador, que é constitutivo da significação, a autora destaca que "[...] a política do silêncio produz um recorte entre o 
que se diz e o que não se diz, enquanto o silêncio fundador não estabelece nenhuma divisão: ele significa em (por) si mesmo" (ORLANDI, 2007, p. 73). Como pudemos observar com base nas considerações arroladas, no cerne da produção do conhecimento não está a essência, o objeto real ou a substância, mas sim o silêncio, o vazio, a barreira e a contradição.

\section{AFINAL, DE ONDE VEM O SENTIDO?}

A língua pensada apenas como um sistema de combinações sintagmáticas e paradigmáticas, apartada da fala e da situação de enunciação, parece perder o seu valor e não produzir sentidos. Um exemplo disso é o Esperanto, que não vingou como língua universal. Apesar de ter um sistema de leis bem definido, esta língua artificial parece não produzir sentidos, pois se apresenta como uma forma sem materialidade, isto é, sem as determinações históricas, políticas, sociais e ideológicas que estão na base da constituição dos sentidos. Outro exemplo bastante frequente para quem trabalha com o ensino de línguas estrangeiras é o fato de muitos alunos reportarem ao professor que sabem bem a gramática, a estrutura da língua, que conseguem fazer qualquer exercício estrutural proposto nos livros de gramática, mas que, ainda assim, não conseguem de fato colocar a língua estrangeira em funcionamento, tomar a palavra e se inserir nesse universo simbólico. A Análise de Discurso trabalha com "a noção de forma material (nem abstrata, nem empírica, mas linguístico-histórica) (ORLANDI, 2016a, p. 13). Essa noção é de grande valia para refletirmos sobre o lugar da linguagem na produção do conhecimento, dos sentidos e das práticas sociais.

No que tange à produção do sentido, a exterioridade (o caráter histórico, social e ideológico do sentido) parece se sobrepor às leis do sistema da língua, tendo em vista que os sentidos não são fixos e se deslocam, se movimentam a cada acontecimento discursivo em que a língua significa em sua relação com a história, sob determinadas condições de produção. Um exemplo disso é o sentido da palavra assédio que, atualmente, está atrelado à esfera jurídica e ao sentido de molestar, causar dano a alguém. Hoje em dia, quando alguém diz que foi assediado, pensa-se, quase que automaticamente, em um ato ilícito passível de punição, uma vez que a este vocábulo foram associadas adjetivações do tipo: assédio moral e assédio sexual. Há alguns anos, no entanto, o dizer "eu fui tão assediada naquela festa", por exemplo, não produzia os mesmos sentidos negativos; pelo contrário, ser assediado, neste exemplo, poderia significar ser bastante procurado ou estar sempre rodeado de pessoas.

A noção de acontecimento discursivo, proposta por Pêcheux (1997, p. 23) como "um ponto em um espaço de disjunções lógicas" nos permite compreender o equívoco, o acaso e a contingência em uma relação de disjunção (e não de junção) com a produção do sentido e das práticas sociais. Daí advém a hipótese desencadeadora deste estudo de que tudo parece ser semelhante ao funcionamento da linguagem porque, de fato, tudo é linguagem! Somos seres de linguagem. Como mencionado anteriormente, até o nosso funcionamento celular, biológico e orgânico parece se aproximar do funcionamento da linguagem. É comum, por exemplo, os médicos afirmarem que fatores externos como o estilo de vida podem ser mais determinantes do que a própria constituição orgânica e biológica do indivíduo. Talvez por isso o mapeamento genético não tenha conseguido atingir sua meta de prever todas as doenças que alguém pode vir a desenvolver: isso não 
depende só de fatores internos ou biológicos. Em certa medida, a empreitada do genoma humano como uma espécie de linguagem universal de todo e qualquer corpo biológico falhou, assim como a linguagem sempre falha ao tentar comunicar algo de forma unívoca, sob a ilusão de ser possível instrumentalizar a língua e os sentidos que dela advêm. Assim como a linguagem é opaca, não transparente, e resulta de um arranjo simbólico, tal como a compreendemos na perspectiva discursiva, Chiaretti (2017, p. 154) nos esclarece que as ciências biológicas apagam o fato de um corpo "ser marcado por uma opacidade, colonizado a cada momento por um certo arranjo simbólico", já que esse corpo é sempre atravessado e significado na/pela linguagem. Temos, aí, uma estreita relação entre o modo como a linguagem e o corpo se constituem e produzem sentidos.

Chiaretti (2017, p. 151) se lança na compreensão da produção de sentido do discurso da Engenharia Genética, em que "o "genoma humano" é significado como o texto fundamental que confere unidade à humanidade". A autora também explora a relação que se estabelece entre corpo, sujeito e sentidos, a partir de práticas discursivosociais. Ao abordar o papel da ciência na produção de saberes sobre o corpo, a referida autora destaca que "a ciência, enquanto discurso, é efeito de condições históricas de produção e, por isso, não pode ser tomada como neutra e objetiva" (2017, p. 152), embora produza um efeito de neutralidade, ao colocar em funcionamento determinadas técnicas que legitimam o discurso da ciência tais como o uso de estatísticas, de dados quantificáveis, a indeterminação do sujeito, generalizações, etc. Nas palavras da autora (2017, p. 153), "as ciências biológicas se configuram como um terreno fértil para o recobrimento pensamento/linguagem/mundo, na medida em que produzem "métodos de apreensão do real" reconhecidamente aceitos e legitimados". Acredita-se, portanto, que há uma relação direta entre pensamento e mundo na produção do conhecimento, esquecendo-se da natureza opaca e não transparente da linguagem e de seu funcionamento.

Darwin, em sua obra de 1859, A origem das espécies, já destacava o papel determinante do meio para transformação e evolução das espécies. O fato de uma espécie ser ou não ser de determinada maneira, isto é, apresentar determinada constituição orgânica e biológica dependeria, segundo o autor, de condições externas ao organismo vivo. Isso explicaria o porquê da existência de uma variedade de seres vivos na natureza. A própria natureza faz uma 'seleção natural' que é determinante para a sobrevivência e evolução de determinada espécie. Sobre a impossibilidade de fixar as leis que governam os caracteres herdados geneticamente, Darwin afirma que:

\footnotetext{
The laws governing inheritance are quite unknown; no one can say why the same peculiarity in different individuals of the same species, and individuals of different species, is sometimes inherited and sometimes not so; why the child often reverts in certain characters to its grandfather or grandmother or other much more remote ancestor; why a peculiarity often transmitted from one sex to both sexes, or to one sex alone, more commonly but not exclusively to the like sex. ${ }^{3}$
}

\footnotetext{
3 “As leis que governam a hereditariedade são bem desconhecidas; ninguém pode dizer por que a mesma particularidade em diferentes indivíduos da mesma espécie, e indivíduos de diferentes espécies, às vezes é herdade e outras vezes não; por que a criança frequentemente retorna a certas características de seu avô ou avó ou de ancestrais muito mais distantes; por que uma peculiaridade muitas vezes transmitida de um sexo para ambos os sexos, ou para um sexo sozinho, é mais comumente mas não exclusivamente transmitida para o mesmo sexo" (tradução nossa).
} 
$\mathrm{Na}$ citação acima podemos observar o quanto as leis que governam a hereditariedade também estão sujeitas ao acaso, às contingências, e o quanto é difícil precisar e fixar tais leis. Fazendo um paralelo com a linguagem e com a produção do sentido e do conhecimento, podemos afirmar que não há leis fixas e rígidas que garantam a produção de certos sentidos e não de outros. $O$ vazio, a contingência e a exterioridade jamais se apagam e não são passíveis de controle. É como num jogo: por mais que saibamos as regras a seguir e que estas sejam fixas, o resultado da partida é sempre inesperado. Na citação de Darwin, as leis que governariam a herança genética também são, em grande medida, desconhecidas, por mais que possam ser observadas, descritas e estudadas. Há sempre um resto que resiste à simbolização, mas que não inviabiliza a produção do conhecimento, pelo contrário, o desloca, o produz o tempo todo. Não se trata de simplesmente questionar se o objeto de conhecimento permite ou não a apropriação do objeto real, mas de olhar para a contradição constitutiva da Ciência e das práticas sociais, tendo em vista que estamos fadados à errância simbólica, pois há linguagem que só significa na relação com a exterioridade que é constitutiva dos sentidos.

Tomando de empréstimo as palavras de Pêcheux ([1966] 2016, p. 21) "quando se trata de avaliar o estatuto de uma prática que pretende alcançar a categoria de ciência", não nos preocupa "decidir sobre seu caráter lícito ou ilícito", mas sim, acrescentaríamos, compreender como esse conhecimento se produz e se legitima, afetado pela exterioridade. Ao postular a contradição "inerente à construção do objeto próprio de toda ciência", Henry (2013, p. 15) se vale de uma citação de Lacan do seminário XI sobre os quatro conceitos fundamentais da Psicanálise, quando Lacan se interroga a respeito da cientificidade da Psicanálise: "Pode-se sustentar que uma ciência é especificada por um objeto definido, pelo menos por um certo nível de operação, reprodutível, que chamamos experiência. Mas devemos ser muito prudentes porque esse objeto muda, e singularmente, no curso da evolução de uma ciência" (LACAN apud HENRY, 2013, p. 15-16). Assim sendo, podemos afirmar que é muito mais a 'escolha' do objeto que define e localiza uma ciência, do que o conhecimento sempre mutável produzido a partir deste objeto. Trata-se, portanto, de não ignorarmos ou silenciarmos o caráter histórico, social e ideológico, inerente ao processo de produção do conhecimento e que traz em seu bojo a contradição e o equívoco próprios à linguagem e à produção do sentido.

Já que o sentido não é fixo, nem está colado à palavra, destacamos a importância de atentar para os gestos de interpretação ou, para usar um termo saussuriano, para o ponto de vista que está presente na definição do objeto de uma ciência. De modo geral, no processo de produção do conhecimento científico, o gesto de interpretação se apaga para aparecer como evidência e verdade imaginariamente guardada e descoberta por uma ciência e não como um saber construído discursivamente, sob determinadas condições de produção. As reflexões e exemplos aqui apresentados reforçam a importância de se considerar a exterioridade, aquilo que a princípio nos escapa e que é crucial para a produção do conhecimento, dos sentidos e do sujeito. 
AGAMBEN, G. Homo Sacer: o poder soberano e a vida nua I. Tradução de Henrique Burigo. 2. ed. Belo Horizonte: Editora UFMG, 2010.

CHIARETTI, P. Corpo e sujeito no discurso da engenharia genética. In: Revista Línguas e Instrumentos Linguísticos, n. 40, p. 151-165, jul.-dez. 2017.

CONEIN, B.; COURTINE, J.-J.; GADET, F.; MARANDIN, J. M.; PÊCHEUX, M. (Org.).

Materialidades discursivas. Campinas: Editora da UNICAMP, [1981] 2016.

CORRÊA, I. A Psicanálise e seus paradoxos: seminários clínicos. Salvador: Ágalma; Recife: Centro de Estudos Freudianos do Recife, 2001.

DARWIN, C. R. [1859] The Origin of Species. Wordsworth Editions Limited, 1998.

HENRY, P. A ferramenta imperfeita. Campinas: Editora da Unicamp, 2013.

KAFKA, F. Diante da lei. In: KAFKA? Um Médico Rural (contos). São Paulo: Editora Brasiliense [1919] 1991.

LACAN, J. (1971-1972 [1997]). O saber do psicanalista. Recife: Centro de Estudos Freudianos do Recife (publicação para circulação interna).

ORLANDI, E. Análise de Discurso: princípios e procedimentos. Campinas: Pontes Editores: 1999.

ORLANDI, E. As formas do silêncio: no movimento dos sentidos. Campinas: Editora da Unicamp, 2007.

ORLANDI, E. Nota introdutória à tradução brasileira. In: CONEIN, B.; COURTINE, J-.J.; GADET, F.;

MARANDIN, J. M.; PECCHEUX, M. (Org.). Materialidades discursivas. Campinas: Editora da UNICAMP, 2016a. p. 9-16.

ORLANDI, E. Ler Michel Pêcheux hoje. In: ORLANDI, E. P. (Org.). Análise de Discurso: Michel Pêcheux - textos selecionados. Campinas: Pontes Editores, 4. ed., 2016b. p. 11-20.

PÊCHEUX, M. O Discurso: estrutura ou acontecimento. Tradução de Eni Orlandi. Campinas: Pontes, 1997.

PÊCHEUX, M. [Thomas Herbert (1966)]. Reflexões sobre a situação teórica das ciências sociais e, especialmente, da psicologia social. In: ORLANDI, E. P. (Org.). Análise de Discurso: Michel Pêcheux. Textos selecionados. 4. ed. Campinas: Pontes, 2016. p. 21-54.

REHEM, C. O amor e o (a)muro frente à impossibilidade da relação sexual. In: LEITE, N.; AIRES, S. [Org.]. Prática da letra, uso do inconsciente. Campinas: Mercado de Letras, 2016. p. 333-338.

SAUSSURE. F. Curso de Linguística Geral. São Paulo: Editora Cultrix, [1916] 1994.

\section{AGRADECIMENTOS}

Agradeço a Allan Strottmann, aluno egresso do Programa de Pós-Graduação em Ciências da Linguagem da Univás, cujas contribuições foram fundamentais para o desenvolvimento e embasamento do presente estudo. Agradeço, ainda, às minhas filhas, Luiza e Beatriz, cujas conversas sobre a produção e circulação do conhecimento na instituição escolar também motivaram a escolha temática deste estudo.

Este texto está licenciado com uma Licença Creative Commons Atribuição 4.0 Internacional. 